\title{
Article \\ Reduction of Chlorinated Ethenes by Ag- and Cu-Amended Green Rust
}

\author{
Edward J. O'Loughlin ${ }^{1,2, *(1)}$ and David R. Burris ${ }^{1,3}$ \\ 1 Air Force Research Laboratory, AFRL/MLQR, Tyndall AFB, IL 32403-5301, USA; dave@burris-net.com \\ 2 Biosciences Division, Argonne National Laboratory, Argonne, IL 60439-4843, USA \\ 3 Crooked Creek Environmental, LLC, Panama City, FL 32401-4039, USA \\ * Correspondence: oloughlin@anl.gov; Tel.: +1-630-252-9902
}

Citation: O'Loughlin, E.J.;

Burris, D.R. Reduction of Chlorinated

Ethenes by Ag- and Cu-Amended

Green Rust. Minerals 2022, 12, 138.

https: / / doi.org/10.3390/min

12020138

Academic Editor: Carlito Tabelin

Received: 8 January 2022

Accepted: 24 January 2022

Published: 25 January 2022

Publisher's Note: MDPI stays neutral with regard to jurisdictional claims in published maps and institutional affiliations.

Copyright: () 2022 by the authors. Licensee MDPI, Basel, Switzerland. This article is an open access article distributed under the terms and conditions of the Creative Commons Attribution (CC BY) license (https:// creativecommons.org/licenses/by/ $4.0 /)$.

\begin{abstract}
Chlorinated ethenes have been used extensively as solvents, degreasers, and dry-cleaning agents in a range of commercial and industrial applications. This has created a legacy of contaminated soils and groundwater, particularly with respect to perchloroethylene (PCE; a.k.a. tetrachloroethene$\mathrm{C}_{2} \mathrm{Cl}_{4}$ ), and trichloroethylene (TCE; a.k.a. trichloroethene- $-\mathrm{C}_{2} \mathrm{HCl}_{3}$ ), prompting the development of a wide array of treatment technologies for remediation of chlorinated ethene-contaminated environments. Green rusts are highly redox-active layered Fe(II)-Fe(III) hydroxides that have been shown to be facile reductants for a wide range of organic and inorganic pollutants. The reduction of chlorinated ethenes [vinyl chloride (VC); 1,1-dichloroethene(11DCE), cis-1,2-dichloroethene (c12DCE), trans-1,2-dichloroethene (t12DCE), TCE, and PCE] was examined in aqueous suspensions of green rust, alone as well as with the addition of $\mathrm{Ag}(\mathrm{I})(\mathrm{AgGR})$ or $\mathrm{Cu}(\mathrm{II})$ (CuGR). Green rust alone was ineffective as a reductant for the reductive dechlorination for all of the chlorinated ethenes. Nearcomplete removal of PCE was observed in the presence of AgGR, but all other chlorinated ethenes were essentially non-reactive. Partial removal of chlorinated ethenes was observed in the presence of CuGR, particularly 11DCE (34\%), t12DCE (51\%), and VC (66\%). Significant differences were observed in the product distributions of chlorinated ethene reduction by AgGR and CuGR. The effectiveness of $\mathrm{Ag}(\mathrm{I})$ - and $\mathrm{Cu}(\mathrm{II})$-amended green rusts for removal of chlorinated ethenes may be improved under different conditions (e.g., $\mathrm{pH}$ and interlayer anion) and warrants further investigation.
\end{abstract}

Keywords: reductive dechlorination; catalysis; perchloroethene; tetrachloroethene; trichloroethene; dichloroethane; vinyl chloride

\section{Introduction}

Green rusts are layered Fe(II)-Fe(III) hydroxides with a pyroaurite-type structure with alternating positively charged $\mathrm{Fe}(\mathrm{II})$-Fe(III) hydroxide layers and hydrated anion layers with the general composition: $\left[\mathrm{Fe}(\mathrm{II})_{1-x} \mathrm{Fe}(\mathrm{III})_{x}(\mathrm{OH})_{12}\right]^{x+}\left[(\mathrm{A})_{x / n} y \mathrm{H}_{2} \mathrm{O}\right]^{x-}$, where $\mathrm{A}$ is an $n$-valent anion (e.g., $\mathrm{Cl}^{-}, \mathrm{F}^{-}, \mathrm{SO}_{4}{ }^{2-}$, or $\mathrm{CO}_{3}{ }^{2-}$ ), $x$ is the molar fraction of $\mathrm{Fe}(\mathrm{III})$ typically ranging from 0.25 to 0.33 , and $y$ denotes varying amounts of interlayer water $(y=2$ to 4$)$ [1]. Green rusts are key components of the biogeochemical cycling of Fe in aquatic and terrestrial systems and are formed during microbial reduction of Fe(III) oxides [2-12], during direct microbial or coupled biotic/abiotic oxidation of Fe(II) under anoxic conditions by denitrifying bacteria [13-16], and during abiotic and microbially induced corrosion of iron and steel [17-20]. As such, they are found in Fe(II)-Fe(III) transition zones in a variety of natural and engineered environments including surface waters [21], groundwater [22,23], soils [24-29], sediments [30-32], and permeable reactive barriers [33-38], often as the minerals fougérite, trébeurdenite, and mössbauerite [39-41]. Furthermore, green rusts are highly redox-active and have been shown to be facile reductants for a wide range of organic and inorganic pollutants including nitrate, toxic metals, metalloids, radionuclides, azo dyes, nitroaromatics, and halogenated hydrocarbons [42-65]. 
Chlorinated methanes, ethanes, and ethenes have been used extensively as solvents, fumigants, degreasers, and dry-cleaning agents, with annual production in the millions of tons. Their use in a range of commercial and industrial applications, as well as from improper disposal, has created a legacy of contaminated soils and groundwater, particularly with respect to carbon tetrachloride (CT; a.k.a. tretrachloromethane- $\mathrm{CCl}_{4}$ ), chloroform (CF; a.k.a. trichloromethane- $\mathrm{CHCl}_{3}$ ), methylene chloride (DCM; a.k.a. dichloromethane$\mathrm{CH}_{2} \mathrm{Cl}_{2}$ ), 1,1,1-trichloroethane (111TCA; $\mathrm{C}_{2} \mathrm{H}_{3} \mathrm{Cl}_{3}$ ), 1,2-dichloroethane (12DCA; $\mathrm{C}_{2} \mathrm{H}_{4} \mathrm{Cl}_{2}$ ), perchloroethylene (PCE; a.k.a. tetrachloroethene $-\mathrm{C}_{2} \mathrm{Cl}_{4}$ ), and trichloroethylene (TCE; a.k.a. trichloroethene- $\mathrm{C}_{2} \mathrm{HCl}_{3}$ ) [66-68]. Many of these chlorinated compounds are acute toxins, carcinogens, mutagens, and endocrine disruptors [69], prompting the development of a wide array of treatment technologies for remediation of contaminated environments, which often entail reductive dechlorination to non-chlorinated products [70,71].

The reductive dehalogenation of halogenated hydrocarbons by green rust has been the focus of several studies, beginning with the work by Erbs et al. [46] showing reduction of CT to CF and PCE by sulfate green rust $\left(\mathrm{GR}_{\mathrm{SO}}\right.$, i.e., green rust with sulfate as the interlayer anion). CF was also the main product of the reduction of $\mathrm{CT}$ by chloride green rust $\left(\mathrm{GR}_{\mathrm{Cl}}\right)$, along with methane $\left(\mathrm{CH}_{4}\right)$ and a trace of ethane $\left(\mathrm{C}_{2} \mathrm{H}_{6}\right)$ [72]. O'Loughlin et al. examined the reduction of the entire series of chlorinated methanes by $\mathrm{GR}_{\mathrm{SO} 4}$ and found that $\mathrm{CT}$ was readily reduced to $\mathrm{CF}$ and carbon monoxide $(\mathrm{CO})$, as well as trace amounts of methane and PCE; $\mathrm{CF}$ was minimally reactive and only trace amounts of methane, DCM, ethane, and ethene $\left(\mathrm{C}_{2} \mathrm{H}_{4}\right)$ were observed and DCM and chloromethane $\left(\mathrm{CM} ; \mathrm{CH}_{3} \mathrm{Cl}\right)$ were non-reactive [73]. Hexachloroethane $\left(\mathrm{HCA} ; \mathrm{C}_{2} \mathrm{Cl}_{6}\right)$ is readily reduced to PCE by $\mathrm{GR}_{\mathrm{SO} 4}$ and minor products consisting of pentachloroethane (PCA: $\mathrm{C}_{2} \mathrm{HCl}_{5}$ ), $\mathrm{TCE}$, ethene, and ethane $[45,57]$. As with the chlorinated methanes, the extent of reduction of lesserchlorinated ethane analogs by $\mathrm{GR}_{\mathrm{SO} 4}$ generally decreased with decreasing number of chlorines [57]. In contrast to the facile reduction of CT and HCA by green rust, most studies of the reduction of PCE (the fully chlorinated endmember of the chlorinated ethene series) by green rust indicate no or very limited reduction [74-78]; however, modest reduction of PCE $(<35 \%)$ has been reported [53,72]. Likewise, green rusts have typically been found to support limited to no reduction of lesser chlorinated ethenes [53,72,76-78].

Several approaches have been developed to enhance the rates and extent of reduction of chlorinated methanes, ethanes, and ethenes by facilitating electron transfer from green rust to the chlorinated hydrocarbon. O'Loughlin et al. found that the addition of $\operatorname{Ag}(\mathrm{I})$, $\mathrm{Au}(\mathrm{III})$, or $\mathrm{Cu}(\mathrm{II})$ to green rust suspensions increased the reduction rates of chlorinated methanes and ethanes by up to three orders of magnitude [57,73]. Furthermore, the overall extent of transformation was enhanced, both in terms of the amount of parent compound reduced, as well as the fraction of reactions products consisting of non-chlorinated products. Likewise, the addition of $\mathrm{Cu}$ (II) or $\mathrm{Pt}(\mathrm{IV})$ to green rust suspensions increased the rates, extents, and fraction of non-chlorinated reaction products of PCE and TCE $[72,75,79]$. Ayala-Luis et al. reported that the reduction of CT by green rust intercalated with the surfactant dodecanoate $\left(\mathrm{GR}_{\mathrm{C} 12}\right)$ was 27 -fold faster than with unaltered $\mathrm{GR}_{\mathrm{SO} 4}$ and that the final products were primarily $\mathrm{CO}(>54 \%)$ and formic acid $(>6 \%)$, with only minor amounts of $\mathrm{CF}(<6.3 \%)$ [80]. The addition of $\mathrm{Cu}(\mathrm{II})$ to $\mathrm{GR}_{\mathrm{C} 12}$ lead to $\mathrm{CT}$ reduction that was 37-fold faster than with $\mathrm{GR}_{\mathrm{C} 12}$ alone and the formation of DCM and CM [81]. The presence of graphene oxide increased the reduction of $\mathrm{CT}$ relative to green rust alone; however, $\mathrm{CF}$ is the end product of the reaction [82]. Recently, Ai et al. reported that the addition of bone char to green rust suspensions resulted in the near-complete reduction of PCE, TCE, cis-1,2-dichloroethene (c12DCE: $\mathrm{C}_{2} \mathrm{H}_{2} \mathrm{Cl}_{2}$ ), and trans-1,2-dichloroethene (t12DCE: $\mathrm{C}_{2} \mathrm{H}_{2} \mathrm{Cl}_{2}$ ) to acetylene ( $>85 \%$ ) [78]; no reduction was observed in the presence of either bone char or green rust alone. These results show that modified or amended green rust may be effective agents for the reductive dechlorination of chlorinated hydrocarbons including chlorinated ethenes. 
No previous studies of chlorinated ethene reduction by green rusts (native or modified) have examined the entire chlorinated ethene series. Therefore, the objective of this study is to examine the potential of native and metal-amended $[\mathrm{Ag}(\mathrm{I})$ and $\mathrm{Cu}(\mathrm{II})]$ green rust for reductive dechlorination of PCE, TCE, 1,1-dichloroethene (11DCE: $\mathrm{C}_{2} \mathrm{H}_{2} \mathrm{Cl}_{2}$ ), c12DCE, t12DCE, and chloroethene (a.k.a. vinyl chloride (VC) $-\mathrm{C}_{2} \mathrm{H}_{3} \mathrm{Cl}$ ).

\section{Materials and Methods}

\subsection{Chemicals}

PCE (99.9+\%), TCE (99.9+\%), (99\%), c12DCE (97\%), t12DCE) (98\%), iron(II) sulphate heptahydrate (99+\%), Cu(II) chloride (99.999\%), $\mathrm{Ag}(\mathrm{I})$ acetate $(99.999 \%)$, propene $\left(\mathrm{C}_{3} \mathrm{H}_{6} ; 99+\%\right)$, n-heptane $\left(\mathrm{C}_{7} \mathrm{H}_{16} ; 99+\%\right)$, 1-butene $\left(\mathrm{C}_{4} \mathrm{H}_{8} ; 99+\%\right)$, and a mixture of cisand trans-2-butene $\left(\mathrm{C}_{4} \mathrm{H}_{8} ; 38.1 \%\right.$ cis and $61.6 \%$ trans) were obtained from Aldrich. A multi-component gas mixture containing methane, ethane, ethane, and acetylene (each at 1.0 mole $\%$ in $\left.\mathrm{N}_{2}\right)$, propane $\left(\mathrm{C}_{3} \mathrm{H}_{8} ; 1.002 \%\right.$ in $\left.\mathrm{N}_{2}\right)$, $n$-butane $\left(\mathrm{C}_{4} \mathrm{H}_{10} ; 1.0 \%\right.$ in $\left.\mathrm{N}_{2}\right)$, and VC, $\left(0.1 \%\right.$ in $\left.\mathrm{N}_{2}\right)$ were purchased from Scott Specialty Gases. Sulfate green rust was synthe-

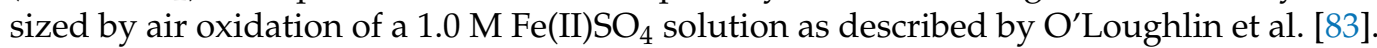
X-ray diffraction (XRD) analysis of the $\mathrm{GR}_{\mathrm{SO} 4}$ suspension showed it to be free of other crystalline Fe-bearing solid phases (e.g., goethite, lepidocrocite, magnetite) [83]. The GR SO4 $_{4}$ consisted of nominally hexagonal, platy, 100-500 $\mu \mathrm{m}$ wide crystallites (Figure S1) with a surface area of $14.1 \mathrm{~m}^{2} \mathrm{~g}^{-1}$, as determined by five-point Brunauer-Emmett-Teller (BET) $\mathrm{N}_{2}$ adsorption [73]. Ag-amended and $\mathrm{Cu}$-amended $\mathrm{GR}_{\mathrm{SO}}$ (AgGR, and CuGR, respec-

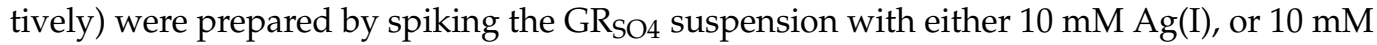
$\mathrm{Cu}(\mathrm{II})$ [73], resulting in the formation of $\mathrm{Ag}(0)$ or $\mathrm{Cu}(0)$ nanoparticles and partial oxidation of the $\mathrm{GR}_{\mathrm{SO} 4}$ to magnetite $\left(\mathrm{Fe}_{3} \mathrm{O}_{4}\right)$ [58].

\subsection{Experimental Setup}

The experiments were conducted in $160 \mathrm{~mL}$ serum bottles as described by $\mathrm{O}^{\prime}$ Loughlin and Burris [57]. Initial solution concentrations were $30 \mathrm{mM}$ Fe(II) as GR $\mathrm{SO}_{\mathrm{SO}}$ and $100 \mu \mathrm{M}$ $\mathrm{Ag}(\mathrm{I})$ or $\mathrm{Cu}(\mathrm{II})$ (except for controls containing green rust only). Reactions were initiated by the addition of $2 \mu \mathrm{L}$ of a $1.0 \mathrm{M}$ methanolic solution of the chlorinated ethene of interest, resulting in $2 \mu \mathrm{mol}$ of halogenated ethane in each bottle. The $\mathrm{pH}$ of the experimental systems was $7.6 \pm 0.1$. Chlorinated ethenes and the main non-chlorinated products of their reductive dechlorination (Figure 1) are sufficiently volatile that their concentrations in the experimental system can be monitored by measuring their headspace concentrations [84]. Therefore, at selected times, $200 \mu \mathrm{L}$ headspace samples were removed from the serum vials for analysis using a Hewlett-Packard 5890 Series II gas chromatograph (Avondale, PA, USA) as described by O'Loughlin and Burris [57]. 


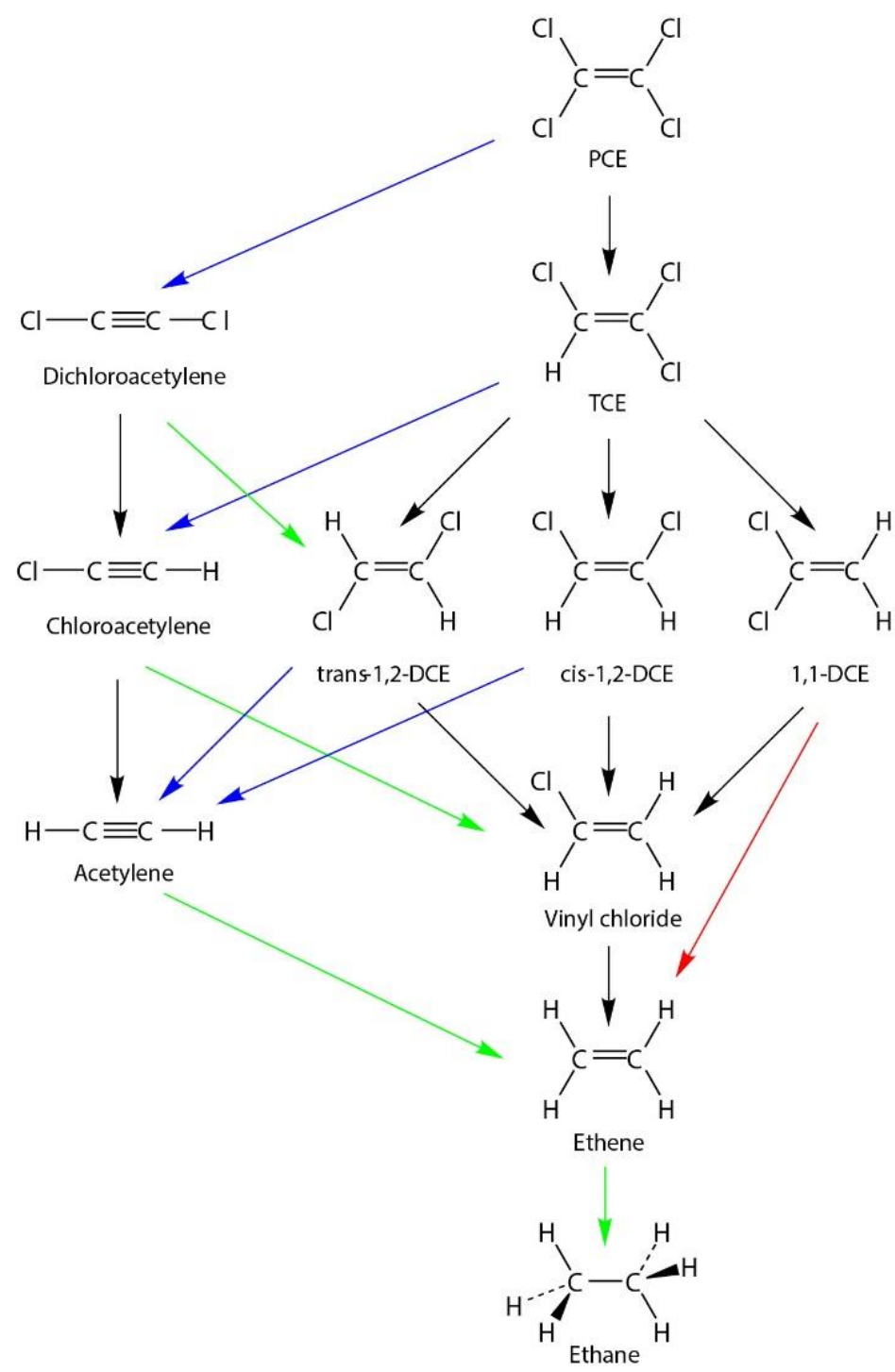

Figure 1. Potential pathways for the reduction of chlorinated ethenes (modified from [85]). The blue arrows designate $\beta$-elimination reactions $\left(\mathrm{RCl}=\mathrm{RCl}+2 e^{-} \rightarrow \mathrm{R} \equiv \mathrm{R}+2 \mathrm{Cl}^{-}\right)$, red indicates $\alpha$-elimination $\left(\mathrm{R}=\mathrm{RCl}_{2}+2 e^{-} \rightarrow \mathrm{R} \equiv \mathrm{R}+2 \mathrm{Cl}^{-}\right)$, green designates hydrogenation $\left(\mathrm{R} \equiv \mathrm{R}+2 e^{-}+2 \mathrm{H}^{+} \rightarrow \mathrm{HR}=\mathrm{RH}\right.$ or $\left.\mathrm{R}=\mathrm{R}+2 e^{-}+2 \mathrm{H}^{+} \rightarrow \mathrm{HR}-\mathrm{RH}\right)$, and black designates hydrogenolysis $\left(\mathrm{R}=\mathrm{RCl}+2 e^{-}+\mathrm{H}^{+} \rightarrow \mathrm{R}=\mathrm{RH}+\mathrm{Cl}^{-}\right)$. $\mathrm{PCE}=$ perchloroethene; $\mathrm{TCE}=$ trichloroethene; 11DCE = 1,1-dichloroethene; $\mathrm{c} 12 \mathrm{DCE}=$ cis-1,2-dichloroethene; and trans-1,2-DCE = trans-1,2-dichloroethene.

\section{Results and Discussion}

\subsection{Reduction of Chlorinated Ethenes by $\mathrm{GR}_{\mathrm{SO} 4}$}

Plots of concentration versus time for the chlorinated ethenes in aqueous suspensions with $\mathrm{GR}_{\mathrm{SO} 4}$ are shown in Figure 2 and mass recoveries of the reactants and volatile products (chlorinated ethenes, acetylene, ethene, and ethane) are given in Table 1. No reaction products were detected, although water-soluble reactions products such as acetate and acetaldehyde (for which our headspace analysis would have had low sensitivity) have been observed or postulated as minor products of chlorinated ethene reduction $[86,87]$, and may have been present. The absence of volatile reaction products and $>95 \%$ recovery of the chlorinated ethenes (except for 86\% PCE recovery) at the end of the experiment indicate that $\mathrm{GRSO}_{\mathrm{SO}}$ was not an effective reductant for any of the chlorinated ethenes under our experimental conditions. The incomplete mass recovery for PCE is not likely due to chemical transformation of PCE, rather, minor amounts of PCE may have been lost to sorption to the septum or to green rust [53]. 

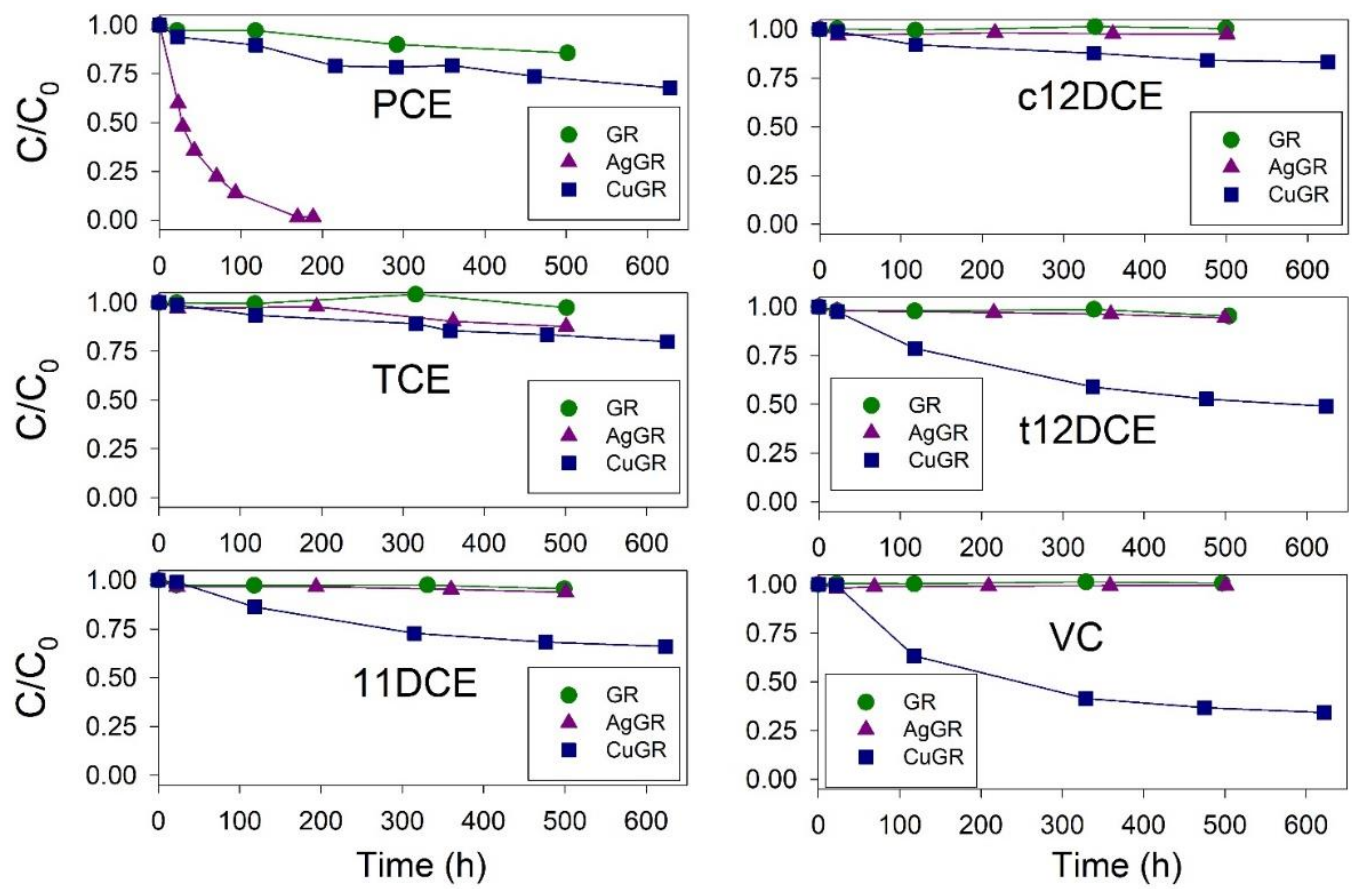

Figure 2. Reduction of chlorinated ethenes in aqueous suspensions containing $2 \mu \mathrm{mol}$ of the indicated compound and $0.5 \mathrm{~g}$ of $\mathrm{GR}_{\mathrm{SO} 4}$ either without (GR) or with the addition of $10 \mu \mathrm{mol}$ of $\mathrm{Ag}(\mathrm{I})$ (AgGR) or $\mathrm{Cu}(\mathrm{II})(\mathrm{CuGR})$. Lines are for visualization purposes only. PCE = perchloroethene; $\mathrm{TCE}=$ trichloroethene; $11 \mathrm{DCE}=1,1$-dichloroethene; $\mathrm{c} 12 \mathrm{DCE}=$ cis-1,2-dichloroethene; $\mathrm{t} 12 \mathrm{DCE}=$ trans-1,2-dichloroethene; and VC = vinyl chloride. The data for Figure 2 is provided in Table S1.

Table 1. The extents of chlorinated ethene removal, final product distributions, and carbon recoveries in aqueous suspensions of unamended green rust (GR), and green rust amended with $10^{-4} \mathrm{M}$ of either $\mathrm{Ag}(\mathrm{I})$ or $\mathrm{Cu}(\mathrm{II})$ (AgGR and CuGR, respectively).

\begin{tabular}{|c|c|c|c|c|c|}
\hline Compound $^{a}$ & System & Final Sampling (h) & Compound Remaining & Products $^{a}$ & Carbon Recovery ${ }^{b}$ \\
\hline \multirow{3}{*}{ PCE } & GR & 502 & $85.7 \%$ & ND & $85.7 \%$ \\
\hline & AgGR & 189 & $1.5 \%$ & $\begin{array}{c}\operatorname{TCE}(87.4 \%), \operatorname{t12DCE}(7.3 \%) \\
\operatorname{AC}(7.4 \%) \text {, and } \operatorname{EE}(0.5 \%)\end{array}$ & $104.2 \%$ \\
\hline & CuGR & 627 & $67.9 \%$ & $\mathrm{TCE}(6.3 \%), \mathrm{EE}(3.3 \%)$, and $\mathrm{EA}(0.3 \%)$ & $77.7 \%$ \\
\hline \multirow{3}{*}{ TCE } & GR & 501 & $97.4 \%$ & ND & $97.4 \%$ \\
\hline & AgGR & 501 & $87.6 \%$ & $\mathrm{AC}(1.8 \%)$ and $\mathrm{EE}(1.1 \%)$ & $89.9 \%$ \\
\hline & CuGR & 625 & $79.9 \%$ & $\mathrm{EE}(11.1 \%)$ and $\mathrm{EA}(1.1 \%)$ & $92.1 \%$ \\
\hline \multirow{3}{*}{ 11DCE } & GR & 499 & $95.7 \%$ & ND & $95.7 \%$ \\
\hline & AgGR & 501 & $93.8 \%$ & $\mathrm{EE}(0.3 \%)$ & $94.1 \%$ \\
\hline & CuGR & 624 & $66.1 \%$ & $\mathrm{EE}(30.2 \%)$ and $\mathrm{EA}(2.8 \%)$ & $99.1 \%$ \\
\hline \multirow{3}{*}{ c12DCE } & GR & 500 & $100.0 \%$ & ND & $100.0 \%$ \\
\hline & AgGR & 501 & $97.4 \%$ & $\mathrm{EE}(0.1 \%)$ & $97.5 \%$ \\
\hline & CuGR & 625 & $83.1 \%$ & $\mathrm{VC}(1.0 \%), \mathrm{EE}(14.9 \%)$, and $\mathrm{EA}(1.5 \%)$ & $100.5 \%$ \\
\hline \multirow{3}{*}{$\mathrm{t} 12 \mathrm{DCE}$} & GR & 504 & $95.2 \%$ & ND & $95.2 \%$ \\
\hline & AgGR & 499 & $94.2 \%$ & $\mathrm{AC}(0.8 \%), \mathrm{EE}(0.3 \%)$, and $\mathrm{EA}(0.1 \%)$ & $95.3 \%$ \\
\hline & CuGR & 623 & $48.9 \%$ & $\mathrm{EE}(42.6 \%)$ and $\mathrm{EA}(4.5 \%)$ & $96.9 \%$ \\
\hline \multirow{3}{*}{$\mathrm{VC}$} & GR & 497 & $100.0 \%$ & ND & $100.0 \%$ \\
\hline & AgGR & 501 & $99.5 \%$ & ND & $99.5 \%$ \\
\hline & CuGR & 622 & $34.2 \%$ & $\mathrm{EE}(58.2 \%)$ and $\mathrm{EA}(7.4 \%)$ & $99.8 \%$ \\
\hline
\end{tabular}

${ }^{a} \mathrm{PCE}=$ perchloroethene; TCE $=$ trichloroethene; $11 \mathrm{DCE}=1,1$-dichloroethene; $\mathrm{c12 \textrm {DCE }}=$ cis-1,2-dichloroethene $\mathrm{t} 12 \mathrm{DCE}=$ trans-1,2-dichloroethene; $\mathrm{VC}=$ vinyl chloride; $\mathrm{AC}=$ acetylene; $\mathrm{EE}=$ ethene; $\mathrm{EA}=$ ethane; and $\mathrm{ND}=$ no products detected. ${ }^{b}$ Carbon molar balance of identified products and any remaining parent compound relative to the initial moles of parent compound.

Our results are consistent with previous studies showing no reduction of polychlorinated ethenes by green rusts $\left(\mathrm{GR}_{\mathrm{SO} 4}, \mathrm{GR}_{\mathrm{CO} 3}, \mathrm{GR}_{\mathrm{Cl}}\right.$, and $\left.\mathrm{GR}_{\mathrm{F}}\right)[75,77,78]$; however, others 
have reported significant, if not complete, reduction of polychlorinated ethenes and vinyl chloride by green rusts $[53,72,74,76,88]$. The variability in the reactivity of green rust with chlorinated ethenes has been attributed to multiple factors including the type of interlayer anion, surface area, $\mathrm{pH}, \mathrm{Fe}(\mathrm{II}) / \mathrm{Fe}(\mathrm{III})$ ratio, and amount of $\mathrm{Fe}(\mathrm{II})$ sorbed on the green rust, and artifacts from GR preparation and handling $[53,72,76,77,88]$. Interlayer anion composition has been shown to affect the rate of reduction of nitrate, chromate $[\mathrm{Cr}(\mathrm{VI})]$, and $\mathrm{U}(\mathrm{VI})$ by green rust $[43,48,52]$, and Liang et al. [76] observed faster rates of PCE and TCE reduction with $\mathrm{GR}_{\mathrm{Cl}}$ relative to $\mathrm{GR}_{\mathrm{SO} 4}$, which they attributed to the greater surface area of the $\mathrm{GR}_{\mathrm{Cl}}$ used in their study. Han et al. [88] observed a decrease in the reduction rates of c12DCE and VC with increasing $\mathrm{pH}$, which they ascribed to increasing amounts of Fe(II) on the green rust surface with increasing $\mathrm{pH}$. Conversely, both Lee and Batchelor [53] and Maithreepala and Doong [72] reported a decrease in the rates of TCE and PCE reduction with increasing $\mathrm{pH}$. Lee and Batchelor suggested their results could be explained by an increase in the overall thermodynamic driving force of the reaction at high $\mathrm{pH}$ due to the lower concentration hydrogen ions, a product of the dechlorination reaction, or to the increase in formation of hydroxide functional groups on green rust, which are presumed to be more reactive reductants. The lack of a consistent pattern in the reactivity of chlorinated ethenes with green rusts suggests that the observed differences in reactivity are perhaps due to multiple, often interrelated, factors.

\subsection{Reduction of Chlorinated Ethenes by Ag-Amended $G R_{\mathrm{SO}}$}

As with the un-amended GR, there was essentially no dechlorination of VC and the DCEs by AgGR (Figure 2), as reaction products accounted for only $0.1-1.1 \%$ of the carbon mass balance (Table 1). TCE concentration decreased by $\sim 12 \%$ over $501 \mathrm{~h}$ in the presence of AgGR, but only 3\% was recovered as reaction products (acetylene and ethene). However, within 189 h, PCE was nearly completely transformed to TCE (87.4\%), t12DCE $(7.3 \%)$, and acetylene (7.4\%). The distribution of the reaction products suggests that PCE is primarily transformed to TCE via hydrogenolysis (Figure 1), with TCE being essentially a terminal product as reduction of TCE by AgGR was minimal (Figure 2). However, some transformation of PCE to dichloroacetylene via $\beta$-elimination (Figure 1 ) is suggested by the formation of t12DCE and acetylene. Dichloroacetylene was not observed as an intermediate; however, this is not surprising given that it is rapidly dechlorinated to chloroacetylene via hydrogenolysis and to t12DCE via hydrogenation [89]. Given that t12DCE is essentially unreactive with AgGR, it is unlikely that $\beta$-elimination of t12DCE contributed significantly to the observed production of acetylene during PCE reduction (Figure 1). Rather, acetylene was likely the result of hydrogenolysis of chloroacetylene. As with dichloroacetylene, chloroacetylene was not observed as an intermediate; however, like dichloroacetylene, it is easily dechlorinated via hydrogenolysis, resulting in acetylene $[89,90]$. The formation of acetylene from the dechlorination of TCE by AgGR and the non-reactivity of lesser chlorinated ethenes suggests transformation of TCE to chloroacetylene via $\beta$-elimination, with subsequent reduction to acetylene (Figure 1). Reductive dechlorination of PCE and TCE by transition metal species often results in the formation of non-chlorinated $\mathrm{C}_{3}-\mathrm{C}_{6}$ alkanes and alkenes $[85,86,90-93]$ attributed to radical coupling reactions; however, no such products were detected resulting from PCE reductive dechlorination by AgGR.

\subsection{Reduction of Chlorinated Ethenes by $\mathrm{Cu}$-Amended $\mathrm{GR}_{\mathrm{SO}}$}

With the exception of PCE, chlorinated ethene reduction by CuGR was enhanced relative to AgGR or unamended GR (Figure 2). Over $622 \mathrm{~h}, 65.6 \%$ of VC was reduced to ethene $(58.2 \%)$ and ethane $(7.4 \%)$, consistent with dechlorination of $\mathrm{VC}$ via hydrogenolysis followed by hydrogenation of ethene to ethane (Figure 1). Approximately $50 \%$ of t12DCE was transformed to ethene $(42.6 \%)$ and ethane $(4.5 \%)$. These products could result from t12DCE dechlorination via $\beta$-elimination resulting in acetylene, and hydrogenation of acetylene to ethene or via sequential hydrogenolysis reactions forming $\mathrm{VC}$ then ethene; however, in either case, the initial transformation product (acetylene or VC) never accumu- 
lated at detectable concentrations. CuGR was less effective at dechlorination of c12DCE, with $>80 \%$ remaining after $625 \mathrm{~h}$. The product distribution (VC (1.0\%), ethene (14.9\%), and ethane (1.55) is consistent with $12 \mathrm{DCE}$ dechlorination via sequential hydrogenolysis reactions, although the potential for dechlorination by the $\beta$-elimination pathway cannot be discounted. Within $624 \mathrm{~h}, \sim 44 \%$ of 11DCE was dechlorinated in the presence of CuGR, resulting in ethene (30.2\%) and ethane (2.85). Ethene could be produced directly from $11 D C E$ via an $\alpha$-elimination reaction or via serial hydrogenolysis (Figure 1 ).

Although greater than in the presence of AuGR or unamended GR, the dechlorination of TCE in the CuGR system was limited, with $\sim 80 \%$ remaining after $625 \mathrm{~h}$. No lesser chlorinated intermediates were detected, but the formation of ethene $(11.1 \%)$ and ethane (1.1\%) suggest the potential for multiple reaction pathways as shown in Figure 1. PCE concentrations decreased by $\sim 32 \%$ within $627 \mathrm{~h}$ accompanied by the formation of TCE $(3.6 \%)$, ethene $(3.3 \%)$ and, ethane $(0.3 \%)$. Similar to TCE, the observed products of PCE reduction may result from multiple reaction pathways. As with AgGR, there was no evidence of the formation of radical coupling products.

\subsection{Comparrison with Other Studies of Chlorinated Ethenes by Metal-Amended Green Rust}

This is the first study to examine the dechlorination of the entire series of chlorinated ethenes by metal-amended green rusts; however, other studies have focused on PCE and TCE. No prior studies have examined chlorinated ethene reduction by Ag-amended green rust; however, Choi and Lee observed enhanced reductive dechlorination of PCE by green rusts amended with $\mathrm{Pt}(\mathrm{IV})$ [75]. PCE was essentially completely transformed to acetylene by chloride, fluoride, carbonate, and sulfate green rusts amended with $\mathrm{Pt}(\mathrm{IV})$, unlike our system with AgGR, in which TCE was the dominant product, with lesser amounts of t12DCE and acetylene (Table 2). Maithreepala and Doong examined the reduction of PCE and TCE in the presence of $\mathrm{Cu}$-amended chloride green rust [72]. Within 35 days, $>85 \%$ of PCE was removed, with TCE $(16.6 \%)$ and ethene (31.95) as the major transformation products. Over the same period in TCE-amended systems, $~ 50 \%$ of TCE was removed, with ethene $(11 \%)$ and ethane $(1 \%)$ as products. Although the overall extents of reaction were greater, the products formed were similar to those observed in our study.

Table 2. coducts in metal-amended green rust systems.

\begin{tabular}{|c|c|c|c|c|c|}
\hline Compound $^{a}$ & Products $a, b$ & $\begin{array}{c}\text { This Study } \\
\text { AgGR }_{\mathrm{SO} 4}\end{array}$ & $\begin{array}{l}\text { Choi and Lee }[79]^{d} \\
\text { PtGR }_{\mathrm{F}}, \mathrm{Cl}, \mathrm{SO} 4, \mathrm{CO} 3\end{array}$ & $\begin{array}{l}\text { This Study } \\
\text { CuGR }_{\mathrm{SO} 4}\end{array}$ & $\begin{array}{c}\text { Maithreepala and } \\
\text { Doong [72] }{ }^{f} \mathrm{CuGR}_{\mathrm{Cl}}\end{array}$ \\
\hline \multirow[t]{8}{*}{ PCE } & & $2.30 \pm 0.09 \times 10^{-2} \mathrm{~h}^{-1 g}$ & $9.93 \pm 0.58 \times 10^{-2} \mathrm{~h}^{-1}$ & $5.96 \pm 0.69 \times 10^{-4} h^{-1}$ & $3.06 \pm 0.39 \times 10^{-1} \mathrm{~h}^{-1}$ \\
\hline & PCE & $1.5 \%$ & $\sim 1-15 \%$ & $67.9 \%$ & $12.4 \%$ \\
\hline & TCE & $87.4 \%$ & - & $6.3 \%$ & $16.6 \%$ \\
\hline & $\mathrm{t} 12 \mathrm{DCE}$ & $7.3 \%$ & - & - & - \\
\hline & acetylene & $7.4 \%$ & $\sim 71-90 \%$ & - & - \\
\hline & ethene & $0.5 \%$ & - & $3.3 \%$ & $31.9 \%$ \\
\hline & ethane & - & - & $0.3 \%$ & $0.1 \%$ \\
\hline & Carbon recovery & $104.2 \%$ & $81-95 \%$ & $77.7 \%$ & $61.0 \%$ \\
\hline \multirow[t]{6}{*}{ TCE } & & $2.44 \pm 0.53 \times 10^{-4} \mathrm{~h}^{-1}$ & - & $3.59 \pm 0.23 \times 10^{-4} \mathrm{~h}^{-1}$ & $\sim 9.58 \times 10^{-4} \mathrm{~h}^{-1}$ \\
\hline & TCE & $87.6 \%$ & - & $79.9 \%$ & $51.0 \%$ \\
\hline & acetylene & $1.8 \%$ & - & - & - \\
\hline & ethene & $1.1 \%$ & - & $11.1 \%$ & $11.0 \%$ \\
\hline & ethane & - & - & $1.1 \%$ & $1.0 \%$ \\
\hline & Carbon recovery & $89.9 \%$ & - & $92.1 \%$ & $63.0 \%$ \\
\hline
\end{tabular}

${ }^{a} \mathrm{PCE}=$ perchloroethene; $\mathrm{TCE}=$ trichloroethene; and t12DCE $=$ trans-1,2-dichloroethene. ${ }^{b}$ Carbon molar balance of identified products and any remaining parent compound relative to the initial moles of parent compound. ${ }^{c}$ Experimental conditions: $\mathrm{pH} \sim 7.6,3 \mathrm{mmol} \mathrm{Fe}(\mathrm{II}), 10 \mu \mathrm{mol} \mathrm{Ag}(\mathrm{I}), 2 \mu \mathrm{mol}$ PCE or TCE, and 8 and 21 day incubation period at $25^{\circ} \mathrm{C}$ for PCE and TCE, respectively. ${ }^{d}$ Experimental conditions: $\mathrm{pH} \sim 7.5,2.0-2.2 \mathrm{mmol}$ Fe(II), $24.3 \mu \mathrm{mol}$ $\mathrm{Pt}(\mathrm{IV}), 6 \mu \mathrm{mol} \mathrm{PCE}$, and 5-26 day incubation period at $25^{\circ} \mathrm{C}$. ${ }^{e}$ Experimental conditions: $\mathrm{pH} \sim 7.6,3 \mathrm{mmol} \mathrm{Fe}(\mathrm{II})$, $10 \mu \mathrm{mol} \mathrm{Cu}(\mathrm{II}), 2 \mu \mathrm{mol}$ PCE or TCE, and 26 day incubation period at $25^{\circ} \mathrm{C}$ for PCE and TCE. ${ }^{f}$ Experimental conditions: pH 7.2, $12.9 \mu \mathrm{mol} \mathrm{Fe}(\mathrm{II}), 25 \mu \mathrm{mol} \mathrm{Cu}(\mathrm{II}), 0.9 \mu \mathrm{mol}$ PCE or TCE, and 35 day incubation period at $25^{\circ} \mathrm{C}$ for PCE and TCE. ${ }^{g}$ Pseudo-first-order rate constants for the reduction of PCE and TCE. The rate constant for PCE reduction from Choi and Lee [79] is from the PtGR $\mathrm{SO}_{4}$ system. 
As discussed in Section 3.1, differences in the reactivity of unamended green rusts with respect to dechlorination of chlorinated ethenes has been linked to several factors, several of which have been investigated in relation to the efficiency of chlorinated ethene reduction by metal-amended green rusts. As with unamended green rust, $\mathrm{pH}$ was found to affect PCE removal efficiency, and the relationship between $\mathrm{pH}$ and PCE removal efficiency was not consistent among experimental systems. Maithreepala and Doong [72] reported that the rates of PCE removal by $\mathrm{Cu}(\mathrm{II})$-amended $\mathrm{GR}_{\mathrm{Cl}}$ increased from $\mathrm{pH} 5.5$ to 7.2 , but decreased at $\mathrm{pH}$ 9, while Choi et al. reported the rates of PCE removal by $\mathrm{C}(\mathrm{II})$-amended $\mathrm{GR}_{\mathrm{F}}$ highest at $\mathrm{pH}$ 11, with decreasing rates at $\mathrm{pH} 9$ and 7.5 [79]. It is possible that the differences in $\mathrm{pH}$ effect on PCE removal rates between these two studies is related to the type of interlayer anion in the green rusts used in each, as differences in PCE removal rates have been reported for $\mathrm{Cu}(\mathrm{II})$ - and $\mathrm{Pt}(\mathrm{IV})$-amended green rusts $\left(\mathrm{F}^{-}>>\mathrm{CO}_{3}{ }^{2-}>>\mathrm{SO}_{4}{ }^{2-}>\mathrm{Cl}^{-}\right.$ and $\mathrm{F}^{-}>\mathrm{Cl}^{-}>\mathrm{SO}_{4}{ }^{2-}>\mathrm{CO}_{3}{ }^{2-}$, respectively) $[75,79]$.

Maithreepala and Doong reported that both the removal efficiency and the rate of PCE removal by $\mathrm{Cu}(\mathrm{II})$-amended $\mathrm{GR}_{\mathrm{Cl}}$ increased with increasing amounts of green rust at a fixed $\mathrm{Cu}$ (II) concentration of $0.5 \mathrm{mM}$ [72]. Similarly, the rates of PCE and TCE removal by $\mathrm{Cu}(\mathrm{II})$ - and $\mathrm{Pt}(\mathrm{IV})$-amended green rusts increased with increasing metal loadings $[72,75,79]$, although in many cases the rates decreased at the highest metal loadings examined, which may have been due to corresponding decreases in Fe(II) levels under these conditions [72,79]. Choi et al. [79] observed an initial increase followed by a leveling off of PCE removal rates by $\mathrm{Cu}(\mathrm{II})$-amended fluoride green rust consistent with saturation of PCE sorption sites at the higher PCE concentrations.

The product distributions of chlorinated ethene reduction by metal-amended green rusts varied based on the metal amendment (Tables 1 and 2), as has been reported for the reduction of chlorinated methanes and ethanes [57,73]. Enhanced reduction of chlorinated hydrocarbons has been reported for $\mathrm{Ag}(\mathrm{I})-, \mathrm{Au}(\mathrm{III})-, \mathrm{Cu}(\mathrm{II})-$, and $\mathrm{Pt}(\mathrm{IV})$-amended green rust, and in each system the metals are reduced by green rust to their zero valent $(\mathrm{ZV})$ forms (i.e, $\operatorname{Ag}(0), \operatorname{Au}(0), \mathrm{Cu}(0)$, and $\operatorname{Pt}(0))[58,72,75]$. The enhanced reduction of chlorinated hydrocarbons by green rust-ZVAg/ $\mathrm{Au} / \mathrm{Cu} / \mathrm{Pt}$ systems may be comparable to the enhanced chlorinated hydrocarbon reduction observed with bimetallic reductants [94-99] consisting of a $\mathrm{ZV}$ noble metal (e.g., $\operatorname{Pd}(0), \operatorname{Pt}(0)$, or $\mathrm{Ni}(0))$ with a more active metal (e.g., $\mathrm{Fe}(0)$ or $\mathrm{Zn}(0))$. The specific mechanism(s) leading to the enhanced effectiveness of these bimetallic systems have not been fully characterized [100]. However, it is known that coupling a noble metal with a more reactive metal accelerates the oxidation of the more reactive metal, forming a galvanic cell wherein the active metal serves as the anode and the noble metal acts as the cathode (where electrons are transferred to the oxidant (e.g., chlorinated hydrocarbons). Such a process has been proposed for the catalytic activity of bimetallic reductants [101], and a similar process may be occurring in the green rust-ZVAg $/ \mathrm{Au} / \mathrm{Cu} / \mathrm{Pt}$ systems. Furthermore, Liu et al. have reported that the kinetics and product distribution of the electrolytic reduction of carbon tetrachloride varies with the metal used for the cathode [102], which is consistent with the differences in the rates/extents and product distributions observed with different green rust-ZV metal systems.

\subsection{Potential Utility of Metal-Amended Green Rusts for Remediation of Chlorinated Ethenes}

$\mathrm{Ag}(\mathrm{I})$ - and $\mathrm{Cu}(\mathrm{II})$-amended green rusts have been shown to be effective reductants for the dechlorination of many chlorinated methanes and ethanes [57,72,73]. Under our experimental conditions, these materials (with a couple of notable exceptions) did not demonstrate a level of reactivity that would make them suitable for use in remediation of chlorinated ethene contamination. However, under different conditions (e.g., $\mathrm{pH}$ and interlayer anion), metal-amended green rusts have demonstrated much higher levels of PCE and TCE removal $[72,75,79]$ than observed in this study, suggesting that the effectiveness of $\mathrm{Ag}(\mathrm{I})$ - and $\mathrm{Cu}(\mathrm{II})$-amended green rusts for removal of chlorinated ethenes could be improved and warrants further investigation. Given the potential ecotoxicology issues involved with the use of $\mathrm{Ag}$ and $\mathrm{Cu}$, as well as the costs associated with precious metals 
like $\mathrm{Ag}$, $\mathrm{Au}$, and $\mathrm{Pt}$, the use of metal-amended green rusts for remediation of chlorinated hydrocarbons is probably best suited to ex situ applications, as this would limit the release of metals to the environment and allow for easier recovery of the Ag, $\mathrm{Au}$, or Pt.

Supplementary Materials: The following are available online at https://www.mdpi.com/article/10 $.3390 / \mathrm{min} 12020138 / \mathrm{s} 1$, Figure S1: Scanning electron micrograph of sulfate green rust $\left(\mathrm{GR}_{\mathrm{SO} 4}\right)$ and Table S1: Data for Figure 2.

Author Contributions: Conceptualization, E.J.O. and D.R.B.; methodology, E.J.O. and D.R.B.; formal analysis, E.J.O.; investigation, E.J.O.; writing—original draft preparation, E.J.O.; writing—review and editing, D.R.B.; and funding acquisition, D.R.B. All authors have read and agreed to the published version of the manuscript.

Funding: This research was funded by the Air Force Office of Scientific Research (AFOSR) and the Environmental Security Technology Certification Program (ESTCP) of the U.S. Department of Defense. Manuscript preparation was funded by the Wetlands Hydrobiogeochemistry Scientific Focus Area (SFA) at Argonne National Laboratory, supported by the Environmental System Science Program, Office of Biological and Environmental Research (BER), Office of Science, U.S. Department of Energy (DOE), under contract DE-AC02-06CH11357. Argonne National Laboratory is a DOE laboratory managed by UChicago Argonne, LLC.

Data Availability Statement: Not applicable.

Acknowledgments: The authors thank three anonymous reviewers for their thoughtful reviews.

Conflicts of Interest: The authors declare no conflict of interest. The funders had no role in the design of the study; in the collection, analyses, or interpretation of data; in the writing of the manuscript, or in the decision to publish the results.

\section{References}

1. Usman, M.; Byrne, J.M.; Chaudhary, A.; Orsetti, S.; Hanna, K.; Ruby, C.; Kappler, A.; Haderlein, S.B. Magnetite and Green Rust: Synthesis, Properties, and Environmental Applications of Mixed-Valent Iron Minerals. Chem. Rev. 2018, 118, 3251-3304. [CrossRef]

2. Fredrickson, J.K.; Zachara, J.M.; Kennedy, D.W.; Dong, H.; Onstott, T.C.; Hinman, N.W.; Li, S.-M. Biogenic iron mineralization accompanying the dissimilatory reduction of hydrous ferric oxide by a groundwater bacterium. Geochim. Cosmochim. Acta 1998, 62, 3239-3257. [CrossRef]

3. Hansel, C.M.; Benner, S.G.; Neiss, J.; Dohnalkova, A.; Kukkadapu, R.K.; Fendorf, S. Secondary mineralization pathways induced by dissimilatory iron reduction of ferrihydrite under advective flow. Geochim. Cosmochim. Acta 2003, 67, 2977-2992. [CrossRef]

4. Borch, T.; Masue, Y.; Kukkadapu, R.K.; Fendorf, S. Phosphate imposed limitations on biological reduction and alteration of ferrihydrite. Environ. Sci. Technol. 2007, 41, 166-172. [CrossRef] [PubMed]

5. Shimizu, M.; Zhou, J.; Schroder, C.; Obst, M.; Kappler, A.; Borch, T. Dissimilatory reduction and transformation of ferrihydritehumic acid coprecipitates. Environ. Sci. Technol. 2013, 47, 13375-13384. [CrossRef] [PubMed]

6. Ona-Nguema, G.; Abdelmoula, M.; Jorand, F.; Benali, O.; Géhin, A.; Block, J.-C.; Génin, J.-M.R. Iron (II,III) hydroxycarbonate green rust formation and stabilization from lepidocrocite bioreduction. Environ. Sci. Technol. 2002, 36, 16-20. [CrossRef] [PubMed]

7. Jorand, F.; Zegeye, A.; Landry, F.; Ruby, C. Reduction of ferric green rust by Shewanella putrefaciens. Lett. Appl. Microbiol. 2007, 45, 515-521. [CrossRef]

8. Jung, J.; Bae, S.; Lee, W. Indirect contact of bio-transformation of lepidocrocite: Role of electron transfer mediator. Sustain. Environ. Res. 2012, 23, 193-198.

9. Boyanov, M.I.; O'Loughlin, E.J.; Kemner, K.M. Iron phase transformations resulting from the respiration of Shewanella putrefaciens on a mixed mineral phase. In Journal of Physics: Conference Series; IOP Publishing: Bristol, UK, 2009; Volume 190, p. 012193. [CrossRef]

10. O'Loughlin, E.J.; Boyanov, M.I.; Flynn, T.M.; Gorski, C.; Hofmann, S.M.; McCormick, M.L.; Scherer, M.M.; Kemner, K.M. Effects of bound phosphate on the bioreduction of lepidocrocite $(\mathrm{g}-\mathrm{FeOOH})$ and maghemite $\left(\mathrm{g}-\mathrm{Fe}_{2} \mathrm{O}_{3}\right)$ and formation of secondary minerals. Environ. Sci. Technol. 2013, 47, 9157-9166. [CrossRef]

11. Dong, Y.; Sanford, R.A.; Boyanov, M.I.; Flynn, T.M.; O'Loughlin, E.J.; Kemner, K.M.; George, S.; Fouke, K.E.; Li, S.; Huang, D.; et al. Controls on iron reduction and biomineralization over broad environmental conditions as suggested by the Firmicutes Orenia metallireducens strain Z6. Environ. Sci. Technol. 2020, 54, 10128-10140. [CrossRef]

12. O'Loughlin, E.J.; Boyanov, M.I.; Gorski, C.A.; Scherer, M.M.; Kemner, K.M. Effects of Fe(III) oxide mineralogy and phosphate on $\mathrm{Fe}(\mathrm{II})$ secondary mineral formation during microbial iron reduction. Minerals 2021, 11, 149. [CrossRef]

13. Chaudhuri, S.K.; Lack, J.G.; Coates, J.D. Biogenic magnetite formation through anaerobic biooxidation of Fe(II). Appl. Environ. Microbiol. 2001, 67, 2844-2848. [CrossRef] 
14. Pantke, C.; Obst, M.; Benzerara, K.; Morin, G.; Ona-Nguema, G.; Dippon, U.; Kappler, A. Green rust formation during Fe(II) oxidation by the nitrate-reducing Acidovorax sp. strain BoFeN1. Environ. Sci. Technol. 2012, 46, 1439-1446. [CrossRef]

15. Etique, M.; Jorand, F.P.; Zegeye, A.; Gregoire, B.; Despas, C.; Ruby, C. Abiotic process for Fe(II) oxidation and green rust mineralization driven by a heterotrophic nitrate reducing bacteria (Klebsiella mobilis). Environ. Sci. Technol. 2014, 48, 3742-3751. [CrossRef]

16. Nordhoff, M.; Tominski, C.; Halama, M.; Byrne, J.M.; Obst, M.; Kleindienst, S.; Behrens, S.; Kappler, A. Insights into nitratereducing $\mathrm{Fe}(\mathrm{II})$ oxidation mechanisms through analysis of cell-mineral associations, cell encrustation, and mineralogy in the chemolithoautotrophic enrichment culture KS. Appl. Environ. Microbiol. 2017, 83. [CrossRef]

17. Bigham, J.M.; Tuovinen, O.H. Mineralogical, morphological, and microbiological characteristics of tubercles in cast iron water mains as related to their chemical activity. In Planetary Ecology; Caldwell, D.E., Brierley, J.A., Brierley, C.L., Eds.; Van Nostrand Reinhold Co.: New York, NY, USA, 1985; pp. 239-250.

18. Génin, J.-M.R.; Refait, P.; Olowe, A.A.; Abdelmoula, M.; Fall, I.; Drissi, S.H. Identification of green rust compounds in the aqueous corrosion processes of steels; the case of microbially induced corrosion and use of 78 K CEMS. Hyperfine Interact. 1998, 112, 47-50. [CrossRef]

19. Kumar, A.V.R.; Singh, R.; Nigam, R.K. Mössbauer spectroscopy of corrosion products of mild steel due to microbiologically influenced corrosion. J. Radioanal. Nucl. Chem. 1999, 242, 131-137. [CrossRef]

20. Refait, P.; Abdelmoula, M.; Génin, J.-M.R. Mechanisms of formation and structure of green rust one in aqueous corrosion of iron in the presence of chloride ions. Corros. Sci. 1998, 40, 1547-1560. [CrossRef]

21. Zegeye, A.; Bonneville, S.; Benning, L.G.; Sturm, A.; Fowle, D.A.; Jones, C.; Canfield, D.E.; Ruby, C.; MacLean, L.C.; Nomosatryo, S.; et al. Green rust formation controls nutrient availability in a ferruginous water column. Geology 2012, 40, 599-602. [CrossRef]

22. Christiansen, B.C.; Balic-Zunic, T.; Dideriksen, K.; Stipp, S.L.S. Identification of green rust in groundwater. Environ. Sci. Technol. 2009, 43, 3436-3441. [CrossRef]

23. Johnson, C.A.; Freyer, G.; Fabisch, M.; Caraballo, M.A.; Küsel, K.; Hochella, M.F. Observations and assessment of iron oxide and green rust nanoparticles in metal-polluted mine drainage within a steep redox gradient. Environ. Chem. 2014, 11, 377. [CrossRef]

24. Feder, F.; Trolard, F.; Klingelhöfer, G.; Bourrié, G. In situ Mössbauer spectroscopy: Evidence for green rust (fougerite) in a gleysol and its mineralogical transformations with time and depth. Geochim. Cosmochim. Acta 2005, 69, 4463-4483. [CrossRef]

25. Génin, J.-M.R.; Bourrié, G.; Trolard, F.; Abdelmoula, M.; Jaffrezic, A.; Refait, P.; Maitre, V.; Humbert, B.; Herbillon, A. Thermodynamic equilibria in aqueous suspensions of synthetic and natural $\mathrm{Fe}(\mathrm{II})-\mathrm{Fe}(\mathrm{III})$ green rusts: Occurrences of the mineral in hydromorphic soils. Environ. Sci. Technol. 1998, 32, 1058-1068. [CrossRef]

26. Refait, P.; Abdelmoula, M.; Trolard, F.; Génin, J.-M.R.; Ehrhardt, J.J.; Bourrié, G. Mössbauer and XAS study of a green rust mineral: The partial substitution of $\mathrm{Fe}^{2+}$ by $\mathrm{Mg}^{2+}$. Am. Mineral. 2001, 86, 731-739. [CrossRef]

27. Trolard, F.; Génin, J.-M.R.; Abdelmoula, M.; Bourrié, G.; Humbert, B.; Herbillon, A. Identification of a green rust mineral in a reductomorphic soil by Mössbauer and Raman spectroscopies. Geochim. Cosmochim. Acta 1997, 61, 1107-1111. [CrossRef]

28. Weatherington-Rice, J.; Bigham, J.M. Buried pre-Illinoian-age lacustrine deposits with "green rust" colors in Clermont County, Ohio. Ohio J. Sci. 2006, 106, 35-44.

29. Latta, D.E.; Boyanov, M.I.; Kemner, K.M.; O'Loughlin, E.J.; Scherer, M.M. Abiotic reduction of uranium by Fe(II) in soil. Appl. Geochem. 2012, 27, 1512-1524. [CrossRef]

30. Bearcock, J.M.; Perkins, W.T.; Dinelli, E.; Wade, S.C. Fe(II)/Fe(III) 'green rust' developed within ocherous coal mine drainage sediment in South Wales, UK. Mineral. Mag. 2006, 70, 731-741. [CrossRef]

31. Bender Koch, C.; Mørup, S. Identification of green rust in an ochre sludge. Clay Miner. 1991, 26, 577-582. [CrossRef]

32. Root, R.A.; Dixit, S.; Campbell, K.M.; Jew, A.D.; Hering, J.G.; O'Day, P.A. Arsenic sequestration by sorption processes in high-iron sediments. Geochim. Cosmochim. Acta 2007, 71, 5782-5803. [CrossRef]

33. Gu, B.; Phelps, T.J.; Liang, L.; Dickey, M.J.; Roh, Y.; Kinsall, B.L.; Palumbo, A.V.; Jacobs, G.K. Biogeochemical dynamics in zero-valent iron columns: Implications for permeable reactive barriers. Environ. Sci. Technol. 1999, 33, 2170-2177. [CrossRef]

34. Johnson, T.L.; Tratnyek, P.G. A column study of the geochemical factors affecting reductive dechlorination of chlorinated solvents by zero-valent iron. In Proceedings of the In-Situ Remediation: Scientific Basis for Current and Future Technologies. Thirty-Third Hanford Symposium on Health and the Environment, Pasco, WA, USA, 7-11 November 1994; Gee, G.W., Wing, N.R., Eds.; Battelle Press: Columbus, OH, USA, 1994; Volume 2, pp. 931-947.

35. Roh, Y.; Lee, S.Y.; Elless, M.P. Characterization of corrosion products in the permeable reactive barriers. Environ. Geol. 2000, 40, 184-194. [CrossRef]

36. Vogan, J.L.; Butler, B.J.; Odziemkowski, M.S.; Friday, G.; Gillham, R.W. Inorganic and biological evaluation of cores from permeable iron reactive barriers. In Designing and Applying Treatment Technolgies: Remediation of Chlorinated and Recalcitrant Compounds; Wickramanayake, G.B., Hinchee, R.E., Eds.; Battelle Press: Columbus, OH, USA, 1998; pp. 163-168.

37. Furukawa, Y.; Kim, J.-W.; Watkins, J.; Wilkin, R.T. Formation of ferrihydrite and associated iron corrosion products in permeable reactive barriers of zero-valent iron. Environ. Sci. Technol. 2002, 36, 5469-5475. [CrossRef]

38. Phillips, D.H.; Watson, D.B.; Roh, Y.; Gu, B. Mineralogical characteristics and transformation during long-term operation of a zerovalent iron reactive barrier. J. Environ. Qual. 2003, 32, 2033-2045. [CrossRef] 
39. Trolard, F.; Bourrié, G.; Abdelmoula, M.; Refait, P.; Feder, F. Fougerite, a new mineral of the pyroaurite-iowaite group: Description and crystal structure. Clays Clay Miner. 2007, 55, 323-334. [CrossRef]

40. Mills, S.J.; Christy, A.G.; Génin, J.M.R.; Kameda, T.; Colombo, F. Nomenclature of the hydrotalcite supergroup: Natural layered double hydroxides. Mineral. Mag. 2012, 76, 1289-1336. [CrossRef]

41. Génin, J.M.R.; Mills, S.J.; Christy, A.G.; Guérin, O.; Herbillon, A.J.; Kuzmann, E.; Ona-Nguema, G.; Ruby, C.; Upadhyay, C. Mössbauerite, $\mathrm{Fe}_{6}{ }^{3+} \mathrm{O}_{4}(\mathrm{OH})_{8}\left[\mathrm{CO}_{3}\right] \cdot 3 \mathrm{H}_{2} \mathrm{O}$, the fully oxidized 'green rust' mineral from Mont Saint-Michel Bay, France. Mineral. Mag. 2014, 78, 447-465. [CrossRef]

42. Lee, W.; Batchelor, B. Reductive capacity of natural reductants. Environ. Sci. Technol. 2003, 37, 535-541. [CrossRef]

43. Bond, D.L.; Fendorf, S. Kinetics and structural constraints of chromate reduction by green rusts. Environ. Sci. Technol. 2003, 37, 2750-2757. [CrossRef]

44. Christiansen, B.C.; Geckeis, H.; Marquardt, C.M.; Bauer, A.; Römer, J.; Wiss, T.; Schild, D.; Stipp, S.L.S. Neptunyl (NpO ${ }^{+}{ }^{+}$ interaction with green rust, $\mathrm{GR}_{\mathrm{Na}, \mathrm{SO} 4}$. Geochim. Cosmochim. Acta 2011, 75, 1216-1226. [CrossRef]

45. Elsner, M.; Schwarzenbach, R.P.; Haderlein, S.B. Reactivity of Fe(II)-bearing minerals toward reductive transformation of organic contaminants. Environ. Sci. Technol. 2004, 38, 799-807. [CrossRef] [PubMed]

46. Erbs, M.; Hansen, H.C.B.; Olsen, C.E. Reductive dechlorination of carbon tetrachloride using iron(II) iron(III) hydroxide sulfate (green rust). Environ. Sci. Technol. 1999, 33, 307-311. [CrossRef]

47. Hansen, H.C.B.; Bender Koch, C.; Nancke-Krogh, H.; Borggaard, O.K.; Sorensen, J. Abiotic nitrate reduction to ammonium: Key role of green rust. Environ. Sci. Technol. 1996, 30, 2053-2056. [CrossRef]

48. Hansen, H.C.B.; Guldberg, S.; Erbs, M.; Bender Koch, C. Kinetics of nitrate reduction by green rusts-Effects of interlayer anion and Fe(II):Fe(III) ratio. Appl. Clay Sci. 2001, 18, 81-91. [CrossRef]

49. Heasman, D.M.; Sherman, D.M.; Ragnarsdottir, K.V. The reduction of aqueous $\mathrm{Au}^{3+}$ by sulfide minerals and green rust phases. Am. Mineral. 2003, 88, 725-738. [CrossRef]

50. Kone, T.; Hanna, K.; Abdelmoula, M.; Ruby, C.; Carteret, C. Reductive transformation and mineralization of an azo dye by hydroxysulphate green rust preceding oxidation using $\mathrm{H}_{2} \mathrm{O}_{2}$ at neutral $\mathrm{pH}$. Chemosphere 2009, 75, 212-219. [CrossRef]

51. Larese-Casanova, P.; Scherer, M.M. Abiotic transformation of hexahydro-1,3,5-trinitro-1,3,5-triazine (RDX) by green rusts. Environ. Sci. Technol. 2008, 42, 3975-3981. [CrossRef]

52. Latta, D.E.; Boyanov, M.I.; Kemner, K.M.; O'Loughlin, E.J.; Scherer, M.M. Reaction of uranium(VI) with green rusts: Effect of interlayer anion. Curr. Inorg. Chem. 2015, 5, 156-168. [CrossRef]

53. Lee, W.; Batchelor, B. Abiotic reductive dechlorination of chlorinated ethylenes by iron-bearing soil minerals. 2 . Green rust. Environ. Sci. Technol. 2002, 36, 5348-5354. [CrossRef]

54. Legrand, L.; El Figuigui, A.; Mercier, F.; Chausse, A. Reduction of aqueous chromate by Fe(II)/Fe(III) carbonate green rust: Kinetic and mechanistic studies. Environ. Sci. Technol. 2004, 38, 4587-4595. [CrossRef]

55. Loyaux-Lawniczak, S.; Refait, P.; Lecomte, P.; Ehrhardt, J.-J.; Génin, J.-M.R. The reduction of chromate ions by Fe(II) layered hydroxides. Hydrol. Earth Syst. Sci. 1999, 3, 593-599. [CrossRef]

56. Myneni, S.C.B.; Tokunaga, T.K.; Brown, G.E., Jr. Abiotic selenium redox transformations in the presence of Fe(II,III) oxides. Science 1997, 278, 1106-1109. [CrossRef]

57. O'Loughlin, E.J.; Burris, D.R. Reduction of halogenated ethanes by green rust. Environ. Toxicol. Chem. 2004, 23, 41-48. [CrossRef] [PubMed]

58. O’Loughlin, E.J.; Kelly, S.D.; Kemner, K.M.; Csencsits, R.; Cook, R.E. Reduction of $\mathrm{Ag}^{\mathrm{I}}, \mathrm{Au}^{\mathrm{III}}, \mathrm{Cu}^{\mathrm{II}}$, and $\mathrm{Hg}^{\mathrm{II}}$ by $\mathrm{Fe}^{\mathrm{II}} / \mathrm{Fe}^{\mathrm{III}}$ hydroxysulfate green rust. Chemosphere 2003, 53, 437-446. [CrossRef]

59. Pepper, S.E.; Bunker, D.J.; Bryan, N.D.; Livens, F.R.; Charnock, J.M.; Pattrick, R.A.D.; Collison, D. Treatment of radioactive wastes: An X-ray adsorption spectroscopy study of the treatment of technetium with green rust. J. Colloid Interface Sci. 2003, 268, 408-412. [CrossRef]

60. Refait, P.; Simon, L.; Génin, J.-M.R. Reduction of $\mathrm{SeO}_{4}{ }^{2-}$ anions and anoxic formation of iron(II)-iron(III) hydroxy-selenate green rust. Environ. Sci. Technol. 2000, 34, 819-825. [CrossRef]

61. Skovbjerg, L.L.; Stipp, S.L.S.; Utsunomiya, S.; Ewing, R.C. The mechanisms of reduction of hexavalent chromium by green rust sodium sulphate: Formation of Cr-goethite. Geochim. Cosmochim. Acta 2006, 70, 3582-3592. [CrossRef]

62. Williams, A.G.B.; Scherer, M.M. Kinetics of Cr(VI) reduction by carbonate green rust. Environ. Sci. Technol. 2001, 35, 3488-3494 [CrossRef]

63. Yan, S.; Boyanov, M.I.; Mishra, B.; Kemner, K.M.; O'Loughlin, E.J. U(VI) reduction by biogenic and abiotic hydroxycarbonate green rusts: Impacts on U(IV) speciation and stability over time. Environ. Sci. Technol. 2018, 52, 4601-4609. [CrossRef]

64. Etique, M.; Zegeye, A.; Gregoire, B.; Carteret, C.; Ruby, C. Nitrate reduction by mixed iron(II-III) hydroxycarbonate green rust in the presence of phosphate anions: The key parameters influencing the ammonium selectivity. Water Res. 2014, 62, 29-39. [CrossRef]

65. O'Loughlin, E.J.; Boyanov, M.I.; Kemner, K.M. Reduction of vanadium(V) by iron(II)-bearing minerals. Minerals 2021, 11, 316. [CrossRef]

66. Moran, M.J.; Zogorski, J.S.; Squillace, P.J. Chlorinated solvents in groundwater of the United States. Environ. Sci. Technol. 2007, 41, 74-81. [CrossRef] [PubMed] 
67. Doherty, R.E. A History of the production and use of carbon tetrachloride, tetrachloroethylene, trichloroethylene and 1,1,1-trichloroethane in the United States: Part 1-Historical background; carbon tetrachloride and tetrachloroethylene. Environ. Forensics 2000, 1, 69-81. [CrossRef]

68. Doherty, R.E. A History of the production and use of carbon tetrachloride, tetrachloroethylene, trichloroethylene and 1,1,1-trichloroethane in the United States: Part 2-Trichloroethylene and 1,1,1-trichloroethane. Environ. Forensics 2000, 1, 83-93. [CrossRef]

69. Henschler, D. Toxicity of chlorinated organic compounds: Effects of the introduction of chlorine in organic molecules. Angez. Chem. Int. Ed. Engl. 1994, 33, 1920-1935. [CrossRef]

70. Xiao, Z.; Jiang, W.; Chen, D.; Xu, Y. Bioremediation of typical chlorinated hydrocarbons by microbial reductive dechlorination and its key players: A review. Ecotoxicol. Environ. Saf. 2020, 202, 110925. [CrossRef]

71. Ebrahimbabaie, P.; Pichtel, J. Biotechnology and nanotechnology for remediation of chlorinated volatile organic compounds: Current perspectives. Environ. Sci. Pollut. Res. Int. 2021, 28, 7710-7741. [CrossRef]

72. Maithreepala, R.A.; Doong, R.-A. Enhanced dechlorination of chlorinated methanes and ethenes by chloride green rust in the presence of copper(II). Environ. Sci. Technol. 2005, 39, 4082-4090. [CrossRef]

73. O'Loughlin, E.J.; Kemner, K.M.; Burris, D.R. Effects of $\mathrm{Ag}^{\mathrm{I}}, \mathrm{Au}^{\mathrm{III}}$, and $\mathrm{Cu}^{\mathrm{II}}$ on the reductive dechlorination of carbon tetrachloride by green rust. Environ. Sci. Technol. 2003, 37, 2905-2912. [CrossRef]

74. Scherer, M.M.; O'Loughlin, E.; Parkin, G.F.; Valentine, R.; Al-Hosney, H.; Handler, R.; Just, C.; Larese-Casanova, P.; Pasakarnis, T.; Smith, S.L. Sustainability of Long-Term Abiotic Attenuation of Chlorinated Ethenes; SERDP Project ER-1369; Department of Defense Strategic Environmental Research and Development Program (SERDP): Alexandria, VA, USA, 2007; pp. 1-47.

75. Choi, J.; Lee, W. Enhanced degradation of tetrachloroethylene by green rusts with platinum. Environ. Sci. Technol. 2008, 42, 3356-3362. [CrossRef]

76. Liang, X.; Philp, R.P.; Butler, E.C. Kinetic and isotope analyses of tetrachloroethylene and trichloroethylene degradation by model Fe(II)-bearing minerals. Chemosphere 2009, 75, 63-69. [CrossRef] [PubMed]

77. Mangayayam, M.C.; Dideriksen, K.; Tobler, D.J. Can or cannot green rust reduce chlorinated ethenes? Energy Procedia 2018, 146, 173-178. [CrossRef]

78. Ai, J.; Yin, W.; Hansen, H.C.B. Fast dechlorination of chlorinated ethylenes by green rust in the presence of bone char. Environ. Sci. Technol. Lett. 2019, 6, 191-196. [CrossRef]

79. Choi, J.; Batchelor, B.; Chung, J. Reductive dechlorination of tetrachloroethylene by green rusts modified with copper. Water Air Soil Pollut. 2010, 212, 407-417. [CrossRef]

80. Ayala-Luis, K.B.; Cooper, N.G.; Koch, C.B.; Hansen, H.C. Efficient dechlorination of carbon tetrachloride by hydrophobic green rust intercalated with dodecanoate anions. Environ. Sci. Technol. 2012, 46, 3390-3397. [CrossRef] [PubMed]

81. Huang, L.Z.; Yin, Z.; Cooper, N.G.A.; Yin, W.; Bjerglund, E.T.; Strobel, B.W.; Hansen, H.C.B. Copper-mediated reductive dechlorination by green rust intercalated with dodecanoate. J. Hazard. Mater. 2018, 345, 18-26. [CrossRef]

82. Huang, L.Z.; Hansen, H.C.; Daasbjerg, K. Graphene oxide-mediated rapid dechlorination of carbon tetrachloride by green rust. J. Hazard. Mater. 2017, 323, 690-697. [CrossRef]

83. O'Loughlin, E.J.; Kelly, S.D.; Csencsits, R.; Cook, R.E.; Kemner, K.M. Reduction of uranium(VI) by mixed iron(II)/iron(III) hydroxide (green rust): Formation of $\mathrm{UO}_{2}$ nanoparticles. Environ. Sci. Technol. 2003, 37, 721-727. [CrossRef]

84. Campbell, T.J.; Burris, D.R. Analysis of chlorinated ethene reduction products in vapor/water phase systems by dual-column, single detector gas chromatography. Int. J. Environ. Anal. Chem. 1996, 63, 119-126. [CrossRef]

85. Campbell, T.J.; Burris, D.R.; Roberts, A.L.; Wells, J.R. Trichloroethylene and tetrachloroethylene in a metallic iron-water vapor batch system. Environ. Toxicol. Chem. 1997, 16, 625-630. [CrossRef]

86. Roberts, A.L.; Totten, L.A.; Arnold, W.A.; Burris, D.R.; Campbell, T.J. Reductive elimination of chlorinated ethylenes, by zero-valent metals. Environ. Sci. Technol. 1996, 30, 2654-2659. [CrossRef]

87. Glod, G.; Brodmann, U.; Angst, W.; Holliger, C.; Schwarzenbach, R. Cobalamin-mediated reduction of cis- and transdichloroethene, 1,1-dichloroethene, and vinyl chloride in homogeneous aqueous solution: Reaction kinetics and mechanistic considerations. Environ. Sci. Technol. 1997, 31, 3154-3160. [CrossRef]

88. Han, Y.S.; Hyun, S.P.; Jeong, H.Y.; Hayes, K.F. Kinetic study of cis-dichloroethylene (cis-DCE) and vinyl chloride (VC) dechlorination using green rusts formed under varying conditions. Water Res. 2012, 46, 6339-6350. [CrossRef] [PubMed]

89. Arnold, W.A.; Roberts, A.L. Pathways of chlorinated ethylene and chlorinated acetylene reaction with Zn(0). Environ. Sci. Technol. 1998, 32, 3017-3025. [CrossRef]

90. O'Loughlin, E.J.; Ma, H.; Burris, D.R. Catalytic effects of Ni-humic complexes on the reductive dehalogenation of chlorinated $\mathrm{C}_{1}$ and $\mathrm{C}_{2}$ hydrocarbons. In Humic Substances: Nature's Most Versatile Materials; Ghabbour, E.A., Davies, G., Eds.; Taylor and Francis, Inc.: New York, NY, USA, 2004; pp. 295-322.

91. Bakac, A.; Espenson, J.H. Mechanistic investigation of carbon-carbon bond formation in the reduction of alkyl halides by organonickel complexes in aqueous solution. J. Am. Chem. Soc. 1986, 108, 719-723. [CrossRef]

92. Arnold, W.A.; Roberts, A.L. Pathways and kinetics of chlorinated ethylene and chlorinated acetylene reaction with Fe(0) particles. Environ. Sci. Technol. 2000, 34, 1794-1805. [CrossRef]

93. O'Loughlin, E.J.; Burris, D.R. Reductive dehalogenation of trichloroethene mediated by wetland DOC-transition metal complexes. In Wetlands and Remediation; Means, J.L., Hinchee, R.E., Eds.; Battelle Press: Columbus, OH, USA, 2000; pp. 1-8. 
94. Cheng, S.-F.; Wu, S.-C. The enhancement methods for the degradation of TCE by zero-valent metals. Chemosphere 2000, 41, 1263-1270. [CrossRef]

95. Xu, Y.; Zhang, W.-X. Subcolloidal Fe/Ag particles for reductive dehalogenation of chlorinated benzenes. Ind. Eng. Chem. Res. 2000, 39, 2238-2244. [CrossRef]

96. Zhang, W.-X.; Wang, C.-B.; Lien, H.-L. Treatment of chlorinated organic contaminants with nanoscale bimetallic particles. Catal. Today 1998, 40, 387-395. [CrossRef]

97. Lien, H.-L.; Zhang, W.-X. Transformation of chlorinated methanes by nanoscale iron particles. J. Environ. Eng. 1999, 125, 1042-1047. [CrossRef]

98. Muftikian, R.; Fernando, Q.; Korte, N. A method for the rapid dechlorination of low molecular weight chlorinated hydrocarbons in water. Water Res. 1995, 29, 2434-2439. [CrossRef]

99. Wan, C.; Chen, Y.H.; Wei, R. Dechlorination of chloromethanes on iron an palladium-iron bimetallic surface in aqueous systems. Environ. Toxicol. Chem. 1999, 18, 1091-1096. [CrossRef]

100. O'Carroll, D.; Sleep, B.; Krol, M.; Boparai, H.; Kocur, C. Nanoscale zero valent iron and bimetallic particles for contaminated site remediation. Adv. Water Resour. 2013, 51, 104-122. [CrossRef]

101. Elliott, D.W.; Zhang, W.-X. Field assessment of nanoscale bimetallic particles for groundwater treatment. Environ. Sci. Technol. 2001, 35, 4922-4926. [CrossRef]

102. Liu, Z.; Arnold, R.G.; Betterton, E.A.; Festa, K.D. Electrolytic reduction of $\mathrm{CCl}_{4}$-Effects of cathode material and potential on kinetics, selectivity, and product stoichiometry. Environ. Eng. Sci. 1999, 16, 1-13. [CrossRef] 